\title{
Analyzing and Improving the Service Quality of Travel Agencies: A Case Study of Sri Lankan Travel Agencies
}

\author{
N. S. Jayawardena \\ National School Of Business Management, Department of Business Management, 309 Dampe - Pitipana Rd, Colombo, Sri Lanka
}

\begin{abstract}
Customer satisfaction is an important aspect to be managed in any organization. In order to improve the quality of service rendered to a particular customer, the company should be aware of exact customer needs and their perception from the customer's point of view. In recent years the Sri Lankan travel industry (both local and foreign tours) has been facing ferocious competition (ICRA Lanka, 2011). The aim of this qualitative research is to study service quality levels offered to customers in travel agencies to gain an idea to set efficient measures. Hence, the service can be improved which will lead to improved profits. The sampling method chosen for this study is "Simple Random Sampling" where every passenger from the frame has an equal chance of being selected. The customer experience analysis is conducted by a total number of 178 respondents. The sample represents $51 \%$ of participated customers. The questionnaire contains statements on five SERVQUAL dimensions presented by Parasuraman et al. (1985) tailored to specific service quality requirements of the travel agency. Based on that model the service quality been measured by considering the five variables as reliability, responsiveness, empathy, assurance and tangibles.
\end{abstract}

Keywords: Travel agency, Service quality, SERVQUAL model, Customer satisfaction

\section{Introduction}

A travel agency is a retail business, that sells travel related products and services, particularly package tours to customers, on behalf of suppliers, such as airlines, car rentals, hotels, sightseeing tours and tour operators etc. In addition to dealing with ordinary tourists, most travel agencies have a separate department focused on arranging travel itineraries for business travelers. Certain travel agencies specialize in commercial and business travel. There are also travel agencies that serve as general sales agents for foreign travel companies, allowing them to have offices in countries other than where their headquarters are located. In Sri Lanka to be registered as an agency a travel agent should satisfy the definition of indication in section 48(1) of the Ceylon tourist board Act No: 10 of 1966. (ICRA Lanka, 2011)The Sri Lankan travelling agency business has seen tremendous changes over the last 5 years as a result of the terrorism, local tours for Northern Province has declined and only foreign tours took place. Presently there are around $80 \%$ of the travel agencies located in Colombo, hub of the commercial, business related activities with high number of travel outlets including high competition for limited business, and the remaining 20\% island wide. (ICRA Lanka, 2011)

In Sri Lanka, most of the travel agencies are family owned businesses where the owner is the $\mathrm{CEO} /$ manager of the top level with an average of the 4 to 5 frontline counter staff and 3 supporting staff for accounting work, visa formalities and messenger duties. The top level are only responsible for marketing, public relations and negotiating with airlines and other principal activities such as hotel arrangement agreements, legal contractual matters etc.

Most of the times the cost cutting is done via service quality cut downs. As a result decreasing profit margins lead to the ultimate loss of the company. So in order to survive in the long run all the travelling agencies should be aware of the service level expectations of the customer which is the ultimate weapon to increase and sustain the market share. For this purpose 'SERVQUAL' instrument was used to measure the customer's perception about service quality delivered by these travel agencies. Five service quality dimensions; empathy, tangibles, assurance, timeliness and assurance were used in order to measure the customer's perceptions about the service quality of travel agencies in Colombo by considering Shanti Travels which is a leading company in Sri Lanka, as the case company.

\section{Literature Survey}

\section{Service Quality Definition}

In economics, a service is an intangible commodity. That is, services are an example of intangible economic goods. Service quality is a concept developed a considerable interest and debate in the research literature due to difficulties in defining and measuring it with no overall consensus emerging on either.(Wisniewski,2001).According to Gefan (2002), quality is "the subjective comparison that customers make between the quality of the service that they want to receive and what they actually get", also "The difference between customers' expectations for service performance proper to the service encounter and their perceptions of the service rendered." (Gefan, 2002). According to Parasuraman et al. (1988), service quality can be defined as an overall judgment similar to attitude towards the service and generally accepted as an antecedent of overall customer satisfaction (Zeithaml and Bitner, 1996). Parasuraman et al. (1988) have defined service quality as the ability of the organization to meet or exceed customer expectations.

It is the difference between customer expectations of service and perceived service (Zeithaml et al., 1990). Perceived service quality results from comparisons by customers of

\section{Volume 6 Issue 12, December 2017}




\section{International Journal of Science and Research (IJSR) \\ ISSN (Online): 2319-7064}

Index Copernicus Value (2016): 79.57 | Impact Factor (2015): 6.391

expectations with their perceptions of service delivered by the suppliers (Zeithaml et al., 1990). If expectations are greater than performance, then perceived quality is less than satisfactory and hence customer dissatisfaction occurs (Parasuraman et al., 1985; Lewis and Mitchell, 1990).

\section{Models of Service Quality}

\section{The Service Triangle}

The service triangle model was developed by the Christian Gronross (1990). It was a famous model and also called as the service marketing model. Christian Gronross (1990) divided the model by 3 main groups which, run separately but assembles well to achieve organization's targets. These 3 groups are the most important in organizational context as either these three are separate without either one of them organization cannot operate successfully. When considering those three groups company (top management), employees, customers can be taken. The below diagram shows the services marketing model.

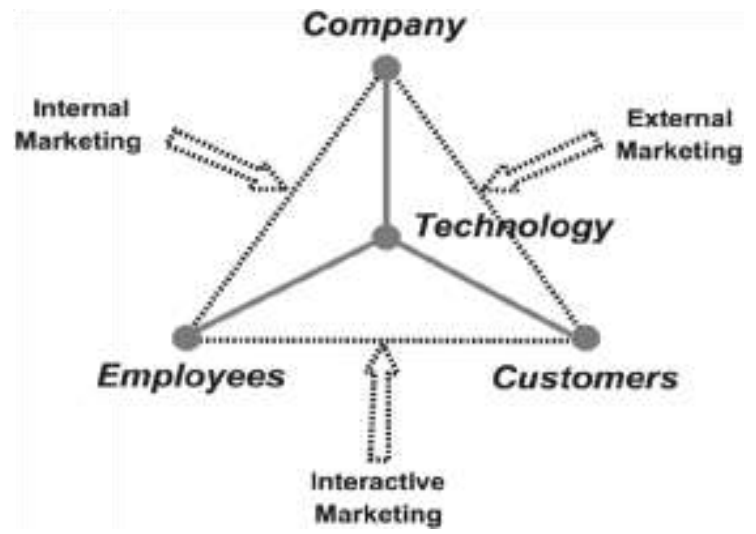

Figure 1: The Service Triangle (Rao, 2004)

\section{THE MOLECULAR MODEL}

Lynn Shostack developed a molecular model to help marketers visualize and manage "total market entity". The molecular model is another useful tool for expanding the understanding of the basic differences between goods or services. This model can be applied to either goods or services. Molecular model is a pictorial representation of the relationship between the tangible and intangible elements of a firm's operation. The overriding benefit obtained by developing molecular models is the appreciation for the intangible and tangible elements that comprises most products. Once managers understand this broadened view of their products they can do a much better job of understanding customer needs, servicing those needs more effectively, and differentiating their product offering from competitors. (Lovelock, 2007)

The molecular model also demonstrates that consumer's service: "knowledge and goods "knowledge" is obtained by focusing in on the physical aspects of the product itself. In contrast, consumers evaluate intangible dominant products based on the experience that surrounds the core-benefit of the product. Hence, understanding the importance and components of the service experience is critical. (Lovelock, 2007)

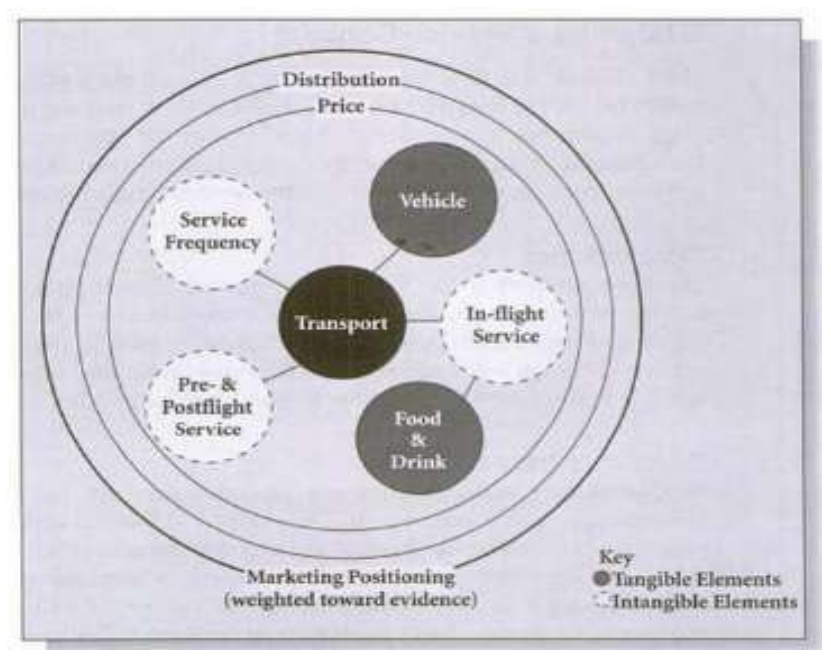

Figure 2: Shostack's Molecular Model: Passenger Airline Service (Lovelock, 2007)

\section{SERVQUAL Model}

The SERVQUAL model proposes that customers evaluate the quality of a service on five distinct dimensions: reliability, responsiveness, assurance, empathy, and tangibles. The SERVQUAL instrument consists of 22 statements for assessing consumer perceptions and expectations regarding the quality of a service. Perceived service quality results from comparisons by consumers of expectations with their perceptions of service delivered by the service providers (Zeithaml et al., 1990).

Service quality is a concept that has aroused considerable interest and debate in the research literature a $s$ the difficulties in both defining it and measuring it with no overall consensus emerging on either (Wisniewski, 2001). There are a number of different "definitions" as to what is meant by service quality.

One that is commonly used defines service quality as the extent to which a service meets customer's needs or expectations (Lewis and Mitchell, 1990; Dotchin and Oakland, 1994a; Asubonteng et al, 1996; Wisniewski and Donnelly, 1996). Service quality can thus be defined as the difference between customer expectations of service and perceived service. If expectations are greater than performance, then perceived quality is less than satisfactory and hence customer dissatisfaction occurs (Parasuraman et al., 1985; Lewis and Mitchell, 1990).Always there exists an important question: why should service quality be measured? Measurement allows for comparison before and after changes, for the location of quality related problems and for the establishment of clear standards for service delivery. Edwards et al. (1994) state that, in their experience, the starting point in developing quality in services is analysis and measurement.

The SERVQUAL approach, which is studied in this paper, is the most common method for measuring service quality. 


\section{International Journal of Science and Research (IJSR) \\ ISSN (Online): 2319-7064}

Index Copernicus Value (2016): 79.57 | Impact Factor (2015): 6.391

(Dr. Arash Shahin Department of Management, University of Isfahan, Iran "A Framework for Determining and Prioritizing Critical Factors in Delivering Quality Services"). In order to improve service quality, it is necessary to contact employees regularly and assess their service experiences. Like the external customer, an internal customer too considers categories of service attributes, such as reliability and responsiveness, in judging the quality of the internal service. With the knowledge of the internal service quality dimensions, the service organizations can then judge how well the organization or employees performed on each dimension and managers could identify the weakness in order to make improvements.

Future research should seek to examine the use of SERVQUAL to close other service quality gaps for different types of organizations. Also, an important issue for future research is about the relationship between internal service quality and external customer satisfaction as well as other constructs, such as employee service orientation, and external service quality. SERVQUAL as the most often used approach for measuring service quality has been to compare customers' expectations before a service encounter and their perceptions of the actual service delivered (Gronroos, 1982)

The SERVQUAL instrument has been the predominant method used to measure consumers' perceptions of service quality. It has five generic dimensions or factors and are stated as follows. (Iwaarden, 2003):

1) Tangibles: Physical facilities, equipment and appearance of personnel.

2) Reliability: Ability to perform the promised service dependably and accurately.

3) Responsiveness: Willingness to help customers and provide prompt service.

4) Assurance: (including competence, courtesy, credibility and security). Knowledge and courtesy of employees and their ability to inspire trust and confidence.

5) Empathy: (including access, communication, understanding the customer). Caring and Individualized attention that the firm provides to its customers.

SERVQUAL instrument performance been measured across these five dimensions, using a five point Likert scale measuring both customer experienced service levels.

\section{Customer Expectations and Perceptions}

The service quality is depending on two variables named as expected customer service level and the perceived customer service level. Service quality as perceived by a travel agency's customers varies from comparison of what they feel the travel agency should offer them vs. their actual experience of the travel agency currently performing. (Zeithaml,1990).Service quality as perceived by the staff and management of the travel agency stems from a comparison of what they feel they should offer to their customers and what actually offering.

So in order to analyze the research problem in detail point of view it is essential to know the importance of how expectations and perceptions are been formed as well as what mainly influence the two variables named as experienced customer service level and the perceived customer service level.

\section{Customer Expectations}

Customer expectations are in a wide variety of scale, where it getting constantly, more sophisticated, increasing, especially now with the emergence of globalization and its powerful influence and competition. (Clegg.2000). Customer expectations can also be defined as customer's partial benefit about a product (Zaahedi, 2002). Expectations are desires and wants of customers which means what they feel a service product should provide these are formed in a basis of past experience with the firm and its competitors and marketing mix inputs. Expectations are more specifically related to the components of the marketing mix which may be extended in the services sector to include physical evidence, process and people. (Booms and Bitner, 1981).

\section{Level of Expectations}

A customer with high experience of quality will perceive the quality of a service as poorer compared to one with lower expectations. This mean that a customer may have low expectations based on earlier experience with the service provider; if those expectations are met there is no gap and service quality is considered satisfactory (Buttle, 1996)

According to the Zeithal et al (1993), he specifically and significantly mentioned that the expectations are composed of different levels rather than a single one.

\section{Customer Experience}

Webster defines this as "an actual living through an event, anything observed or lived through all that has happened to one". (Webster, 1983) An Experience can be defined by "The apprehension of an object thought, or emotion through he senses or mind", active participation in events of activities leading to the accumulation of knowledge or skill.”(www.dictionary.com)

In a business environment "Experiences occur whenever a company intentionally uses services as the stage and goods as props to engage an individual" (Gilmore, 1999).According to the view point of Ali Araghchi, (service quality, customer satisfaction, customer experience and behavioral intention in Iranian retail stores, 2008) customer experience can be categorized to five main components.

- Sense experience -This deals with the five sensors known as sight, touch, taste, smell as customer value creation components.

- Feel experience - This deal with the inner feelings and emotions of the customers where a positive experience links to a brand to strong emotions of joy and pride.

- Think experience - This deal with creating values for customers by nagging them creatively.

- Act experience- This deals with creating value for customers by showing alternative lifestyles behaviors in doing business.

\section{Volume 6 Issue 12, December 2017}




\section{International Journal of Science and Research (IJSR) \\ ISSN (Online): 2319-7064}

Index Copernicus Value (2016): 79.57 | Impact Factor (2015): 6.391

- Relate experience- This deals with social experiences, social identity and sense of belonging.

$\mathrm{He}$ in his article further explained that, "experience in contrast is process oriented, clearly experience provides much more guidance because it forces you to identify the details that result in satisfaction, if you go through the process of managing the customer experience, satisfaction is likely to be one of the results."

The three stages of constrains of an experience defined by Sullivan \& Spangler (1998), analyzed "events or feelings that occur prior, during, and after participation". Components of experience (Bonnie J Knutson. Jeffery a Beck, "Identifying the dimensions of the experience construct: development mode", 2003).

1) Pre experience -anything and everything involved in prior to the actual participation in the experience itself.

2) Participation- The actual involvement in the experience

3) Post experience- the aftermath of participation.

Altogether, when analyzing the customer experience has the simultaneous exposure mentioned as above and varies with one to another customer. (Bonnie, 2003)

\section{Problem Definition}

The below research questions was formed based on the reviewed literature and the research problem.

1) "What relationship exists between service quality dimensions such as reliability, responsiveness, reliability, tangibles, assurance, empathy and the customer satisfaction in the travel agency and how does it affect customer satisfaction"?

2) "What is the current customer satisfaction level regarding the level of service been rendered?"

3) "How to compare the level of perceived customer service with their level or received customer service?"

The above research questions been made in order to get a detailed understanding about the relationship between the service quality dimensions and customer satisfaction as well as the level of customer satisfaction and the gap between perceptions and expectations.

\section{Methodology/Approach}

\subsection{Research Design}

The chosen research method for gathering empirical material was mainly qualitative method.

Quantitative questionnaire was chosen as the data collection method. Additionally company database, annual reports, public statements been used when necessary. As the respondents are entirely external parties the questionnaire was given to them in a random basis. Additionally, interviews are also been used as an extra reference.

\subsection{Research Sample}

The sampling method is "Simple Random Sampling" where every passenger from the frame has an equal chance of being selected. The customer experience analysis is done by a total number of 78 respondents feedback who represents the customers who went tours organized by the company during the month of January 2013 the total number of customers who was participated for the company tours are in total 152 .The sample represents $51 \%$ of participated customers. Therefore, based on their feedbacks the research was conducted.

\subsection{Data Collection}

The questionnaire is a self-completion questionnaire which is a series of questions that respondents answer on their own. This was designed accordingly to the main objective of the research.

The questionnaire contains statements based on, the five SERVQUAL dimensions presented by Parasuraman et al (1985) tailored to specific service quality requirements of the travel agency. Questionnaire has 3 main parts. Part 1 has a sample profile regarding the respondents and part 2 analyses the 5 variables in relation to as questions. Part 3 is the comments which describes the customer feedbacks and their perceptions other than the given questions. The questionnaire was also conducted in both languages due to participant's request. The service quality been analyzed using the customer experience levels using SERVQUAL dimensions.

\section{Conceptual Framework}

The relationship between service quality variables and customer satisfaction can be shown as below based on the reviewed literature. The five service quality dimensions have been selected from the study done by Zeithmal et al (2000:2002).

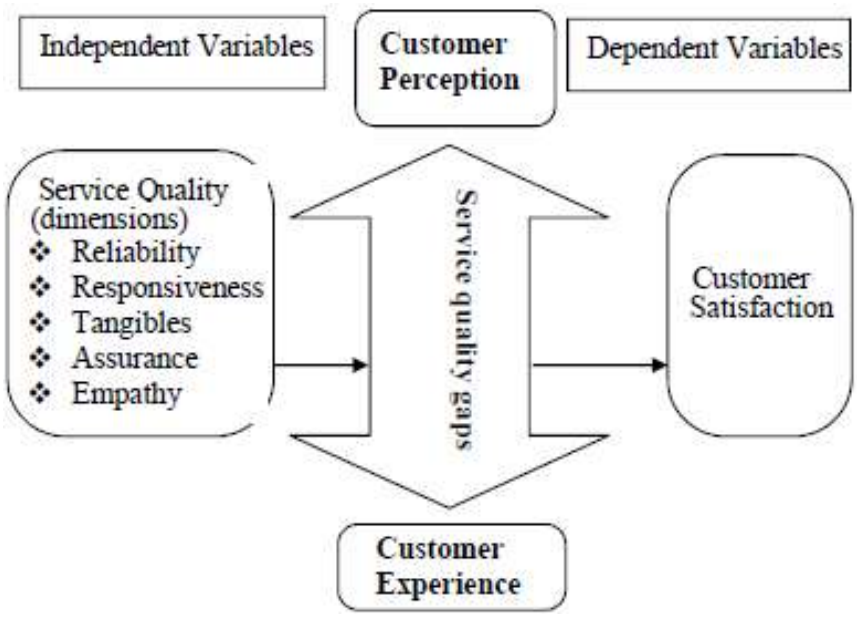

Figure 3: Conceptual Framework

As shown in the conceptual framework, the independent variables can be identified as "Service Quality" which has 5 dimensions as described above. According to Parasuraman et al (1988) the five dimensions of the quality are reliability,

Volume 6 Issue 12, December 2017 


\section{International Journal of Science and Research (IJSR) \\ ISSN (Online): 2319-7064}

Index Copernicus Value (2016): 79.57 | Impact Factor (2015): 6.391

responsiveness, tangibles, assurance, and empathy. The dependent variables can be identified as "customer satisfaction".

First of all the conceptual framework variables been measured to identify whether there is a relationship or not, in order to do this Minitab 15 statistical software has been used.

Table 1: Correlation analysis

\begin{tabular}{|l|l|l|l|l|l|}
\hline & Reliability & Responsiveness & Tangibles & Assurance & Impathy \\
\hline $\begin{array}{l}\text { Pearson } \\
\text { correlation }\end{array}$ & 0.926 & 0.870 & 0.968 & 0.967 & 0.936 \\
\hline p-value & 0.000 & 0.000 & 0.000 & 0.000 & 0.000 \\
\hline
\end{tabular}

The five variables been taken in the conceptual framework has a strong positive linear relationship when considering the correlation coefficient values. This shows that when one variable increases in its values, the other variable also increases in its values via an exact linear rule. The tangibles variable has the highest coefficient correlation. As there are no negative linear relationships (when one variable increases in its values, the other variable decreases in its values via an exact linear rule) the five variables should be measured as there is a relationship enhancing the customer satisfaction.

\section{Multiple Regression Analysis}

The below regression analysis was done to in order to analyze the strength of the linear relationship between two variables. The data analysis of the Minitab software has been presented below.

Table 3: Model Parameters

\begin{tabular}{|c|c|c|c|c|c|}
\hline Model & $\begin{array}{l}\text { Ungt: } \\
\text { Co } \\
B\end{array}$ & $\begin{array}{l}\text { ndarciized } \\
\text { ifficients } \\
\text { | Std. Error }\end{array}$ & $\begin{array}{l}\text { Standarcized } \\
\text { Coefficients } \\
\text { Beta }\end{array}$ & $\mathrm{t}$ & Sig. \\
\hline $\begin{array}{l}\text { (Constant) Reliability } \\
1 \text { Responsiveneas } \\
\text { Assurance } \\
\text { Empatky } \\
\text { Tangibles }\end{array}$ & $\begin{array}{l}-1.359 \\
107 \\
-150 \\
502 \\
392 \\
411\end{array}$ & $\begin{array}{l}154 \\
061 \\
076 \\
096 \\
091 \\
080\end{array}$ & $\begin{array}{l}111 \\
-118 \\
354 \\
312 \\
357\end{array}$ & $\begin{array}{l}-8.829 \\
1.733 \\
-1.980 \\
5.223 \\
4.318 \\
5.121\end{array}$ & $\begin{array}{l}000 \\
087 \\
051 \\
000 \\
000 \\
000\end{array}$ \\
\hline
\end{tabular}

a. Dependent Variable: Customer satisfaction

a. Dependent Variable: Customer satisfaction

- The above model indicates that all the explanatory variables are significant at 5\% level of significance except the variable reliability, which is insignificant at $5 \%$ level of significance.

- Interpretation of Regression Coefficients: (Standardized Coefficients):

- When the Responsiveness increases by one unit the overall customer satisfaction decreases by 0.15 times when the other factors held constant.

- When the factor Empathy increase by one unit the overall customer satisfaction increases by 0.39 times while the other factors held constant.
- Whereas when the Tangibles increase by one unit the overall customer satisfaction increases by 0.4 times while the other factors held constant

Table 4: Model Summary

\begin{tabular}{|l|c|c|c|c|}
\hline Model & R & R Square & $\begin{array}{c}\text { Adjusted } \\
\text { R Square }\end{array}$ & $\begin{array}{c}\text { Std. Error of } \\
\text { the Estimate }\end{array}$ \\
\hline 1 & $.989^{\mathrm{a}}$ & .978 & .977 & .176 \\
\hline
\end{tabular}

a. Predictors: (Constant), Tangibles, Assurance, Responsiveness, Reliability, Empathy.

$\square \mathrm{R}$ square statistic is a goodness of fit test statistic where it says that $97.8 \%$ of the variation of customer satisfaction (dependent variable) is explained by the above regression model.

\section{Further Analysis Using Below Values-Comparative Analysis}

The below vales been taken considering the 5 point Likert scale where weighting of the variables done as below;Values been weighted using as (Strongly disagree: 1,Agree : 2,Neutral :3, Disagree:4,Strongly disagree:5). The mean value calculations done by using the mean value formulas.

Table 5: Data analysis

\begin{tabular}{|l|l|l|l|l|l|l|}
\hline & Reliability & Responsiveness & Tangibles & Assurance & Empathy & $\begin{array}{l}\text { Customer } \\
\text { Satisfaction }\end{array}$ \\
\hline Mean & 3.5724 & 4.3024 & 3.5925 & 3.3971 & 3.3846 & 3.0329 \\
\hline Mode & 5 & 3 & 2 & 3.5 & 3 & 2 \\
\hline Median & 6 & 4 & 3 & 4.5 & 4 & 1 \\
\hline $\begin{array}{l}\text { Std. } \\
\text { Deviation }\end{array}$ & 1.2134 & 0.9149 & 2.1097 & 0.8149 & 0.9224 & 1.1596 \\
\hline Vaniance & 1.4725 & 0.8354 & 4.4511 & 0.6640 & 0.8508 & 1.3432 \\
\hline
\end{tabular}

By using the 5 point likert scale mean values this can be further more analyzed as well as the correlation coefficient and regression analysis also been used. All five dimensions will be analyzed throughout this study in order to assess the effect on customer satisfaction.

\section{Results and Discussion}

\section{Reliability Dimension}

As stated in the literature review reliability dimension is another SERVQUAL dimension. Reliability dimension strength is 0.107 which depicts by the regression analysis showing that when the Reliability increases by one unit the overall customer satisfaction increases by 0.107 times when the other factors held constant. Thus this has a positive linear relationship and the lowest of the other five variables and the second highest after the responsiveness variable which has .0 .150 .

Most probably, this means that this has a lower impact towards the customer satisfaction. Normally, This shows that the ability to perform the promised service dependently and accurately, showing that the Shanti Travels (Pvt) Ltd company is not in a good position with the timeliness in providing the prompt services to customers during the journey as well as should concern on error free service quality, with promised levels of resources and timeliness of 


\section{International Journal of Science and Research (IJSR) \\ ISSN (Online): 2319-7064}

Index Copernicus Value (2016): 79.57 | Impact Factor (2015): 6.391

service been provided. Areas such as complain handling and problem solving system of the company been covered mainly under the reliability dimension under the questionnaire. As a major finding of the research this company should improve the customer care aspect given during the journey towards the customers, and providing the promised levels of resources and facilities as the loss of customer goodwill means a great loss to the company.

\section{Responsiveness Dimension}

As stated in the literature review responsiveness dimension is another SERVQUAL dimension. This variables particular strength is When the Responsiveness increases by one unit the overall customer satisfaction decreases by 0.15 times when the other factors held constant. As this has a reversed relationship with the customer satisfaction levels the company should never be too busy to respond, employees should tell exact time of services, and the employees should be always willing to help the customers. By considering the regression analysis it is explicit that the company currently has not achieved a good status in this aspect where delays and waiting time in providing facilities as well as supportiveness of the staff in different situations throughout the journey is comparably bad.

\section{Assurance Dimension}

As stated in the literature review assurance dimension is another SERVQUAL dimension which has a 0.502 regressions or strength which is the most influencing factor to the customer satisfaction of the company. So as it has the highest impact out of the other 4 variables the company should be aware more on this aspect, so company can improve the quality levels and customers satisfaction as well. So the company as a major finding should improve politeness and hospitality qualities within staff members by proper training and development programmes, workshops etc. safety conditions throughout the journey should also take into consideration whereas the emergency reactions, first aid, ambulance services, proper schedule controlling throughout the journey, special attention to those who are old and disable etc.

\section{Empathy Dimension}

As stated in the literature review empathy dimension is another SERVQUAL dimension. The strength of this is 0.39 which has the third highest impact to customer satisfaction after tangibles aspect. When the factor Empathy increase by one unit the overall customer satisfaction increases by 0.39 times while the other factors held constant.

Individualized attention given during the journey to each customer and reactions towards emergency situations has are thee analyzed areas under this dimension which is another major finding from the analysis been done.

\section{Tangibles Dimension}

As stated in the literature review tangibles are another SERVQUAL dimension. This has the second highest impact towards the customer satisfaction whereas when the Tangibles increase by one unit the overall customer satisfaction increases by 0.4 times while the other factors held constant.
As the questionnaire covered the staff members physical appearance, cleanliness, updated technology, physical facilities should be further improved which shows another major finding from the analysis been done.

\section{Conclusion}

Today's highly competitive business environment in the service industries has resulted in an increased interest in service quality. This is especially true for travel industries where service to customers in interactive and labor intensive. The main focus in the service competitions is the management of moments of truth between customers and employees, and the creation of adequate support from managers, to create value for customers.

The presented research aims in improving the quality levels been provided to customers during the tours. As service is intangible and subject to measure exactly, in order to provide quality service it is essential that there should be an alignment in the values and perceptions of the customers with those staff delivering the service and the managers provide the service specifications.

The research identified areas to be improved in order to improve the quality levels of the company service quality. So by paying more attention towards the variables which has a low regression values has to be improved in order for the customers to be satisfied as well as for company quality improvement. This research has not only opened the door for more work in this area but also has made the managers aware of the need to check the alignment of perception align the value chain in order to provide better service.

\section{Future Scope}

Travel industry is rapidly growing niche market in Sri Lanka. Further research on the customer satisfaction of Shanti Travels (Pvt) Ltd company services provided by the management of the company can be carried out using a larger sample size which would increase the possibility of statistically detecting any patterns or differences in data.

The current research is conducted only taking the view points of the customers who participated in the tours the view points of the travel staff, management, has not taken into account. This research did not take into account the views of the service principals and back up or support staff who also forma part of the process of service delievery.A study including views of customers, management, frontline staff, support staff and service suppliers would provide a more complete picture. Also perception is not static, research and surveys be performed regularly in order to reassess service quality levels in travel agencies. In fact travel agencies do not have the choice than reassess and review service quality constantly in order to retain their existing customers or to attract new ones. Customers are ruthless and quite demanding. If travel agencies want to remain and succeed in business, they should understand what their customers want and what they perceive as service quality. 


\section{International Journal of Science and Research (IJSR) \\ ISSN (Online): 2319-7064}

Index Copernicus Value (2016): 79.57 | Impact Factor (2015): 6.391

\section{Limitations of Study}

- The study examined experienced and perceived quality levels are individual and subjective to issue.

- The SERVQUAL instrument used was adopted and shortened for the purpose of this study and thus affect the validity and reliability of the data.

- The accuracy of the measurement are limited to the 5 variables been examined. However the other variables which effects such as price were not considered.

- When considering the value chain of a travel agency the perception of suppliers, airlines, hotels etc., and other supporting staff such as accountants, visa officers, messengers and receptionist were not considered. These could have provided a more complete picture.

- The research as limited by the scare resource of time. The scarcity of time placed restrictions on the sampling size and method.

\section{References}

[1] Lovelock, C., 2007. Services MarketingPeople,Technology ,Strategy. 6th ed. New Delhi: Dorling Kindersley India (Pvt) Ltd.

[2] Rao, 2004. Services Marketing. 3rd ed. New Delhi: Dorling Kindersley (India) Pvt Ltd.

[3] Baker M (1995). "The Marketing Book". Oxford: Butterworth-Heineman Ltd. 666-667.

[4] Baron and Harris (1995)."Services Marketing, "Macmillan Business-India RS Ltd.231-236.

[5] Bitner, M.J., (1990), "Evaluating Services Encounters: The Effects of Physical Surroundings and Employees Responses, "Journal of Marketing, 54 (April), 69-82

[6] Albert Hamilton (2001). Managing and Controlling Company Quality Levels. 8th Ed. New South Wales: Thomas Telford. 604.

[7] Elaine Marmel (Jun 15, 2011). Microsoft Project 2007 Bible. 2nd ed. John Wiley \& Sons: John Wiley \& Sons. 960.

[8] Albretch, K. (1992). The only thing that matters: Bringing the power of the customer into the center of your business New York: Harper Business .650-651.

[9] Allred, A. T., \& Addams, H. L. (2000). Service quality at banks and credit unions: What do their customers say? Managing Service Quality, 10(1), 52-60.

[10] Anderson, B., \& Langmeyer, L. (1982). The under -50 and over-50 travelers: A profile of similarities and differences. Journal of Travel Research, 20(4), 20-24.

[11] Guy McCord. (2007-2013). Quality management vs Customer satisfaction. The. Human Resource Management. Hut. 5 (8), 2.

[12] Bramwell, B. (1998). User satisfaction and product development in urban tourism. Tourism Management, 19(1), 35-47.

[13] Brysland, A., \& Curry, A. (2001). Service improvements in public sectors using SERVQUAL. Managing Service Quality, 11(6), 389-401.

[14] Butcher, K., Sparks, B., \& McColl-Kennedy, J. (2009). Predictors of customer service training in hospitality firms. International Journal of Hospitality Management, 28, 389-396.
[15]Chen, S., \& Quester, P. G. (2009). A value-based perspective of market Orientation and customer service. Journal Retailing and Consumer Services, 16, 197-206.

[16]Bitner M.J and Hubert A.R (1994). Encounter satisfaction versus overall satisfaction versus quality. India: Sage publications. 72-93.

[17] Giese, J.L and Cote, J.A (2001). Defining Consumer Satisfaction. Academy of Marketing Science, 5 (1): 3443.

[18] Kevin Mitchell. (April 21st, 2011). A Closer Look: Travel Distribution Transparency - Fishbone Diagram Analysis. Open allies for air fare transparency. 11 (1), 5.

[19] Varela. M. J., Boubeta, A. R., AND T. B. Tobio (2001). Consumer preferences and Brand equity of Spanish National Daily Newspaper: A conjoint Analysis Approach. The Spanish Journal of Psychology, 4 (1): 48 -54 .

[20] Davidson, R. \& Cope, B. Business Travel. (2003). Conferences, Incentive Travel, Exhibitions, Corporate Hospitality and Corporate Travel. Prentice Hall. Great Britain 6:72-7

\section{Author Profile}

N. S. Jayawardena, Department of Business Management, National School Of Business Management, Sri Lanka 